\title{
Sowing the Seeds
}

\author{
Tendy Matenge (Corresponding author) \\ Department of Marketing, Faculty of Business, University of Botswana \\ 4775 Notwane Rd, Gaborone, Botswana, \\ Tel: +267-355-4727_E-mail: tendy.matenge@mopipi.ub.bw; m_tendy@yahoo.com
}

Vic Razis

Department of Marketing, Faculty of Business, University of Botswana

4775 Notwane Rd, Gaborone, Botswana,

E-mail: vic.razis@mopipi.ub.bw

Received: December 5, 2011

Accepted: January 9, 2012 Published: March 15, 2012

doi:10.5430/ijba.v3n2p38

URL: http://dx.doi.org/10.5430/ijba.v3n2p38

\begin{abstract}
The key musical note which the authors wish to strike in order to promote a vibrant, harmonious and productive symphony of creative thought, debate and discussion in this paper is simply that Fast Growing African Countries (FGACs), require a very powerful body to provide the money and the business skills to all and any citizens who have a chance of setting up a new small to medium business. Based on the review of the literature and the analysis of the prevailing conditions in Africa, this paper identifies the factors that impact entrepreneurship in the continent and proposes a set of specific interventions that governments of FGACs may instigate to kindle entrepreneurship in their respective countries and the region as a whole. The proposed intervention is the creation of a Centre for Entrepreneurship and Business Skills. The centre would ensure a more business friendly climate, build entrepreneurial capacity, minimize bureaucratic barriers, and elevate the stature of entrepreneurship in Africa. Implementing the proposal advanced in this paper, could have significant implications for new business creation, employment development and economic growth in Africa.
\end{abstract}

Keywords: Entrepreneurship, African Development, SME's

\section{Introduction}

This paper contributes to the entrepreneurship and development literature by exploring key issues surrounding the development and support of SMME's in Fast Growing African Countries (FGACs). The paper provides insight into the support that SMME's in the FGACs need to access in order to ensure their growth. Research of SMME's in this context is important as there is limited research in FGACs, and also, it provides useful insight into the requirement for the advancement and sustainability of SMME's which operate in these taxing regions.

The impact to public policy on SMME's is of global interest (Eshima, 2003; OECD, 1994). In the UK, SMME's are able to apply for grants as part of a package of funding introduced by Business Innovation and Skills (BIS) (Business Innovation and Skills (BIS), 2011), while Enterprise Ireland offers a comprehensive range of support for entrepreneurs and potential start-ups (Enterprise Ireland, 2011). Botswana, long regarded as the success story of Africa, has two statutory bodies to promote and to support entrepreneurship, being the Citizen Entrepreneurial Development Agency (CEDA) and the Local Enterprise Authority (LEA). CEDA was established in 2001 to provide financial and technical support for business development. The aim is to promote viable and sustainable citizen-owned business enterprises. This body offers funding for capital expenditure, for stock, or for working capital in both new and existing businesses (CEDA, 2011). Crucially, it also offers training and mentoring, as well as business advisory services, for new and experienced entrepreneurs. To further enhance the services offered by CEDA, and provide a coordinated and focused one-stop-shop Authority to provide development and support services to local SMME's, Local Enterprising Authority (LEA) was established, and draws Directors from both the private and public sectors (LEA, 2011) - a theme to which we shall return in this paper. 
LEA's support services include training, mentoring, business plan finalisation, market access facilitation, and help in accessing the latest technologies. LEA is intended to be a centre of excellence for entrepreneurship and sustainable SMME sector development in Botswana. The focus is on manufacturing, tourism and agriculture. Access to finance is facilitated. All citizens - the young, men and women, the unemployed, are encouraged towards start-up businesses, towards using local resources, and towards import-substitution and export-orientated products and services.

These entrepreneurs will in turn help to soak up the unemployment, especially amongst young people, which is one of the scourges of Africa (The Economist, 2010; Klasen \& Woolard, 2009). It is well-documented and understood that numerous social, economic and political ills stem directly from joblessness and poverty (Barnabas, Kulkarni, Nanavatty, \& Singh, 1996; Wacquant \& Wilson, 1989; Krivo, Peterson, Rizzo, \& Reynolds, 1998; Hudson, 1996).

In order to stimulate debate, it will be suggested that too few African countries have tackled this problem in an all-embracing and effective way, with the result that unemployment and its attendant ills remain a spectre which haunts all thoughtful people on the continent.

This paper is organized into four sections. These include; Grappling with Opportunities, a section which seeks to accentuate the deficiency of entrepreneurship in the African continent and in the process missing on viable business opportunities. Thereafter, the proposed Centre for Entrepreneurship and Business Skills is introduced, highlighting its potential value to young entrepreneurs in Africa. The section on Concrete Proposals suggests a quadruple alliance for FGACs in the form of a major university campus, government, domestic private business sector, and foreign business sector in the country. Lastly concluding remarks are presented.

\section{Grappling with Opportunities}

Innovation and growth immediately bring to mind entrepreneurship, and the creation of many new small, and maybe medium-sized, businesses (Eshun Jr, 2009; OECD, 2010), since it is generally accepted that both the public sector and big businesses cannot create enough jobs, within their structural limitations, to tackle the enormous job of employing all the people, particularly the young, who want to work, and who need to work, and who need capital and business skills and mentoring, on the African continent.

Using Botswana as one example, there is evidence that, despite significant efforts in the right direction, the culture of entrepreneurship has not been developed sufficiently for citizens to grasp the opportunities which are in fact available to them (Plattner, Lechaena, \& Mmolawa, 2009; Studman, 2003; Hanson, 2008). The African Growth and Opportunity Act (AGOA), which was signed into law by President Clinton in year 2000 has presented opportunities for exporting to the United States which have not been taken advantage of by Batswana business men and women (AGOA, 2011). It has been acknowledged that despite the challenges posed by lack of access to credit, the fundamental problem is lack of exposure to planning tools and models which would strengthen many entrepreneurs' cases for credit (AGOA, 2011; Morewagae \& Seemule, 1995). Furthermore, many Batswana entrepreneurs have been accused of "thinking small" in their business endeavours and thereby passing costs to customers in the form of high prices as they do not enjoy economies of scale (AGOA, 2011; Motseta, 2011).

Therefore, the FGACs need to "think big", but this requires a change in mind-set, notwithstanding the structural economic problems which are bigger than the individual businessperson or even business firms; protectionism (trade-distorting agricultural subsidies), the fact that much of African growth currently depends on the export of one or two main commodities (Congregational Research Service, 2008; Leke, Lund, Roxburgh, \& van Wamelen, 2010), which are subject to price volatility, the logistics of being far from the main trade centres, and so on.

For various reasons, the African continent south of the Sahara escaped the worst ravages of the Great Recession of recent years (Laishley, 2011; Ikome, 2008). This might be an instance in which being slightly cut-off from the mainstream activities of the global economy might have been an advantage, rather than the opposite.

Relative to the global slowdown, Africa's projected growth rates of around 5\% (USAID, 2011; African Development Bank Group, 2011; The Economist, 2011) are very respectable, and have been noted by traders, investors and bankers as well as the financial press. The Economist (2011) singled out the Congo, Ethiopia, Ghana, Mozambique, Nigeria, Tanzania and Zambia as fast-growing economies. Yet others, such as Botswana and South Africa, have the potential to join this group.

Buoyed by a burgeoning retail sector, and by investment in infrastructure, as well as relatively steady demand for tourism and mining, African countries are showing real potential for growth in the coming decade. Technological leap-frogging has helped: many areas which had not yet received the boon of landline telephones are now saturated with mobile phones (Mutula, 2002). Orders for goods and services can be placed and received from the smallest village, to the largest city, with relative ease. 
Despite this surge, sub-Saharan Africa still has structural problems which have been well documented (see Mutula, 2002; Shrum, et al, 2011; Schwartz, 1996; Donner, 2008) and will be only too familiar, so they will not be repeated here. This paper concentrates on the areas of creating new businesses and developing skilled management and labour, in order to help overcome the high levels of unemployment, and the attendant social ills, which still plague much of Africa.

\section{The Potential Value of a Centre for Entrepreneurship and Business Skills}

From the Cape to Cairo, there are numerous bright young business students, or recent graduates, who despair of getting jobs in traditional employment sectors - but who do not appear to consider setting up their own business (except for a few rare cases) to be a viable option for them. That is an indictment of Business Faculties, Policy-Makers, and the domestic and foreign business sectors in most countries from the Cape to Cairo.

Evidence from various studies tends to confirm the observation that too many bright young graduates aspire to jobs in the public sector, in Government or Civil Service, or in large, established corporations, rather than considering starting their own business. In a study carried out in Nigeria on final year university students in the departments of Economics, Business Administration, Accounting and Finance in the 2008/2009 academic session, majority indicated their career choice as either being employed or being employed and doing business part time (50.6 per cent), with 22.6 percent opting for either further studies or further studies and part time business. Only 26.8 percent opted for entrepreneurship as a viable career choice (Ekpoh \& Edet, 2011). In another study in Botswana (University of Botswana), when 135 Faculty of Business undergraduates were asked about their career aspirations only 7 (5.2\%) mentioned entrepreneurship as a viable career choice (Plattner, Lechaena, \& Mmolawa, 2009). Notwithstanding, in South Africa, only 9.3 percent of the Economically Active Population (EAP), as defined by Global Entrepreneurship Monitor (GEM), are self employed (Mlatsheni \& Rospabé, 2002) and results from 701 South African graduates (562 respondents completing their undergraduate degrees and 139 completing postgraduate degrees) showed low entrepreneurial intention amongst graduates (scale mean of 1.65 on a 5 point likert scale) (Fatoki, 2010). When Bachelor of Business Administration students were asked the causes of low business start-ups in Uganda, 47 percent responded that it was because people hope for white collar jobs (Katono, Heintze, \& Byabashaija, 2010), which could partly mean that the education system produces job seekers and not job creators. In general, young graduates seem to have a negative perception towards entrepreneurship which could be as a result of the perception that paid employment is more prestigious (Walter, et al., 2004). Similarly, most Kenyan graduates find it demeaning and unattractive to engage in small and micro enterprises despite the low employment opportunities in Kenya (Maina, 2011). Society feels it owes young graduates while the graduates feel entitled to jobs in government or larger, established multinationals (Maina, 2011). There is no doubt that these institutions are attractive because they offer instant status and financial stability.

An expanding Civil Service, however, does not necessarily add to the skills-set required of a modern economy, and it does not always create productive jobs. On the contrary, expanding ministries tends to suck up valuable resources from the national exchequer. On top of the direct cost to a country in which up to half the working population is employed by Government in one form or another, there is a less-understood opportunity cost: an over-large bureaucracy can actually hinder (through unnecessary and inflexible rules and regulations) the daily productive work of those who can and do produce profits (Bendix, 1947; Savoie, 1994), by providing valuable goods and services, in the economy, and who pay the majority of taxes on which the country depends.

The big corporations, often foreign-owned, offer a few jobs annually to top graduates. Indeed, they are becoming more capital-intensive since the global recession, and are employing fewer people than was the case a few years ago.

If these sectors do not offer either the jobs-enhancing or skills-enhancing functions which are needed to create fast and sustainable growth, and to reduce greatly the rate of unemployment, then of necessity this task is best tackled by the private sector.

However, energetic school-leavers or young graduates often feel that they do not have the minimum capital and management skills required to start and run a business - and it is usually unclear as to where they could turn to acquire these things. Lack of savings and difficulties in obtaining bank finance (lack of collateral) were found to be the biggest obstacles to South African graduates' entrepreneurial intention (Fatoki, 2010). The second most prominent hindrance was the graduates' competency (lack thereof). This consists of lack of skill, information, experience, business plan and an entrepreneurial constituent. In Nigeria, social/cultural attitude towards entrepreneurship, government regulations, education (skills and training) and business support were listed as the most serious constraints faced by young graduates who want to start business (Nwigwe, 2010). Furthermore, Salami (2011) contends that the three major factors that hinder entrepreneurship in Nigeria are structural, cultural, and lack of political will by policy makers. These inhibitors are said to have their roots in the faltering education policies which are not fully thought-out and are inadequately funded. In Zimbabwe it was found that inhibiting factors are lack of appropriate management skills, access to loans, and inhibiting 
legal frameworks (Masuko \& Marufu, 2003). When in Namibia challenges such as the regulatory environment which is not favourable to serve as an incentive for young graduates to set up business hinder their entrepreneurial prowess (Gaomab, 2004).

It is clear that graduates experience similar hindrances across the African region, in lack of access to funds/credit, and lack of entrepreneurial skills/culture. These are a failure of national policy planning. The banks do not help. They usually require collateral to cover the full extent of the loan - if the budding entrepreneur had those resources, they would not need the bank in the first place!

The developing world and Africa in particular, faces a dearth of a young entrepreneurial population. This has and will continue to constrain the region's growth. African governments need to face the reality that young entrepreneurs who can really move the needle on innovation, inspiration and employment need a well-endowed, properly-established, clearly-marketed Centre for Entrepreneurship and Business Skills. This centre could fill the aspiration vacuum which faces Africa's youthful population, and could and should become the focal point for anyone wanting to earn a living as a self-employed entrepreneur.

The linkage between numerous small businesses and the rapid creation of employment around the world has been documented in detail. For instance, Birch (1979) contended that 81.5 percent of the net new jobs between 1969 and 1976 in the United States were created by small and newly established firms. Although Birch's time span of 1969 to 1976 coincided with a recession and consequently, the findings triggered some criticism, it is agreeable that job creation by small and newly established firms contribute a significant percentage in employment creation. Bruderl and Preisendorfer, (2000) found that new firms contributed 35 percent of new jobs in Germany within the first four years of being established. From the findings they extrapolated that newly established firms would contribute 50 percent employment after six years of their establishment. For the United Kingdom, Storey (1994) gave an estimate that small firms contribute about one-third of employment, and similar figures have been reported for West Germany (Fritsch \& Hull., 1987). In sub-Saharan Africa over 40 percent of the labour force in five countries (Botswana, Kenya, Malawi, Swaziland, and Zimbabwe) had been employed by start-up small enterprises (Mead, 1994). Earlier studies have indicated that small firms provided 20 to 45 percent of full time employment and 30 to 50 percent of rural household income (Chuta \& Liedholm, 1990; Haggblade, Hazell, \& Brown, 1989).

Despite this clear linkage, young entrepreneurs in Africa have almost no access to resources that could help nurture their entrepreneurial spirits and assist them in starting businesses. Entrepreneurs struggle to build businesses with meagre resources that rarely allow them to achieve the scale of operations required to be competitive. When entrepreneurs can get a loan, the only form of financing available in the market, the requirement to service the capital on a current basis puts undue pressure on their balance sheet, their ability to re-invest in the growth of their business and their willingness to take risks. In addition, they would lack the necessary skills of managing a small start-up.

\section{Concrete Proposals}

For this reason, it is recommended that a four-part, quadruple, alliance be formed in Fast Growing African Countries (FGACs) consisting of:

- A major University Campus

- Government

- The domestic private business sector

- The foreign business sector in the country

As will be delineated below, this alliance is both necessary and sufficient in terms of pooling together the business expertise and the money required to finance the education, training, start-up and monitoring of the entrepreneur.

Clearly, there would need to be a board representing all four sectors, which would identify and approve potential entrepreneurial enterprise - and then supply all of the training required to run a modern business, and the capital required to make the business plan a reality.

Equally evident, there would need to be an agreed cut-off point beyond which the entrepreneur would be on his or her own.

It should be stressed that the purpose of the four partners is to confer legitimacy and credibility to business plans which are accepted, and to allow for the pooling of expertise and money - but certainly not to make the path towards becoming a successful entrepreneur a bureaucratic and bumpy one. 
The essence of the plan is speed, efficiency and inclusion. The primary aim is to create new firms, and the immediate subsidiary aim is to increase the numbers of skilled participants in the economically-active population - and that population itself.

The problem with plans which have been tried in Sub-Saharan Africa is that they tend to be a little top-heavy, clumsy and bureaucratic, and do little to encourage the quick and efficient spread of an energetic entrepreneurial sector (see: Nelson \& De Bruijn, 2005; Johanson \& Adams, 2004; Bowditch, 1999; Sirolli, 1999).

Specifically, entrepreneurs whose business plans are approved by the board should then have to audit and pass basic, practical courses in the following areas of business expertise:

- Management

- Accounting

- Finance

- Marketing

- IS/IT

- $\mathrm{HR}$

- Company Law \& Taxation (in so far as applicable)

- Operations

- Sales

- Business Strategy

- Importing/Exporting \& International Business generally

There will be other courses which can be added to this basic list, depending upon demand for learning by potential entrepreneurs, and supply of qualified instructors. For example, because of the size of the Government and parastatal sectors in many African countries, there might well need to be training on how to complete complicated tender documents - and to understand the complex rules and regulations which govern the tender process. New business executives and managers need to understand how to differentiate their business from others in the same sector in order to be successful.

Here the neophyte business entrepreneur can benefit enormously from the input of practicing business executives, and also from academics in the field - both of which groups should preferably give of their time for free (social responsibility).

The more the business plan requires the entrepreneur to develop specific skills in him or herself which are valuable to commerce and industry - and to employ others who have themselves to be trained into new skill levels - the more monies should be made available to that particular person(s) and business plan.

Since this plan forces the close cooperation of business practitioners and professors, of law-makers and civil servants, it should be reasonably straightforward for this team effort to come to an understanding of which skills are needed in a particular economy, blessed with unique factor endowments, and what sorts of new businesses would be faced with a robust domestic, regional and international demand.

There are pockets of economic excellence in African countries, but they do not necessarily confer or cooperate with each other in order to realise synergies and economies of scale. Academics in a Faculty of Business might be working on business plans which would be of interest to civil servants, if they knew about them, and vice versa. Business in the same country might be efficient and effective, but its workings unknown to academia and to government.

Given a common and immediate, practical goal, that of identifying and approving, training and monitoring, aspiring entrepreneurs, there is every possibility that the productivity of all those involved will rise simultaneously - to the benefit of the whole country and the region.

As is eminent throughout this paper, education is supposed to empower graduates, improve their lives and provide them with opportunities. Yet for many recent graduates, education has done nothing except provide them with a piece of paper called a degree or diploma. There are thousands of graduates who are willing to work and give their time to their careers and country. But for that to happen, they need an opportunity. However, this is not happening. This issue needs action and that action should have begun long ago. Most graduates are considering leaving Africa, with the hope to find better opportunities abroad. It has been reported that a figure representing more than 6 percent of the physicians practising in 
Sub-Saharan Africa, who were trained in Africa have migrated to the United States, 86 percent of them originating from Nigeria, South Africa, and Ghana (Hagopian, et al, 2001). For the cases of Ghana, Senegal Morocco, and Egypt, the large majority wants to move out of Africa, and the typical potential migrant was found to be young, male of modern values (van Dalen, Groenewold, \& Schoorl, 2005), an age group relatively more inclined to try their luck elsewhere than older groups. An age that is most economically productive and most needed by the African continent.

Africa is not a continent that raises high hopes among development experts and unless action is taken, the lack of economic growth prospects in Africa will only reinforce emigration pressure.

There are, in some African countries, governmental, university and private sector initiatives which are praiseworthy and have good intentions, but they offer Africa's youngsters too little, and, it is worrying, that these initiatives will be too late for the creation of healthy, productive societies.

Too much levy money has been going to short courses which provide little lasting benefit and thus only serve to reproduce cheap labour while purporting to develop skills. The sad fact remains that unemployment in Africa remains unacceptably high, and that the usual governmental initiatives have not made much of a dent in the problem.

Are Universities capable of delivering answers? The current technological waves which are driving the world are born on university campuses. Perhaps that should be the case, and sometimes it is, but all too often, real technological and scientific progress is made by private corporations in search of strategic goals and better returns on investment in R\&D. Therefore a call for an alliance cannot be ignored.

In 30 years there will be 2 billion Africans, and 70 percent of them will be under 20 years old (Population Reference Bureau, 2011). Africa will be providing the world's youth! The befitting question then essentially is: from where, precisely, how, exactly, is the growth and innovation which are required to employ that enormous number of youthful people going to come?

This paper set out to provide some answers as to how to produce growth and encourage innovation, couched in terms of immediate action, that is, money, mentorship, the acquisition of skills and the creation of sustainable new business firms, and hoped to provoke some debate and discourse so as to generate more viable solutions to this eminent African quandary.

There is evidence that excellent work is being done by universities, such as the Graduate School of Business at the University of Cape Town, governments, such as the Botswana Government, private organisations in Africa, and international bodies such as the United Nations, to support entrepreneurship and start-up businesses, but the argument here is that the scale of the current efforts is insufficient to tackle the problem in a way that will produce a genuine solution.

\section{Concluding Remarks}

A large study of 24,000 people from 24 different countries, undertaken amongst others by the University of Maryland in the US (GlobeScan; The Program on International Policy Attitudes, 2011), found wide variations in perceptions of the support which different cultures offer to start-up businesses.

The results, published in May, showed that Indonesia is the best place for entrepreneurs to start a business, with the United States, Canada, India and Australia following closely. China and Nigeria were also perceived by their own people as relatively favourable places for new businesses.

At the other end, Columbia, Egypt, Turkey, Italy and Russia are among the least entrepreneur-friendly.

The respondents were asked whether innovation was highly-valued in their country; whether it was hard for people like them to start a business; whether people who do were highly-valued; and whether people with good ideas could usually put them into practice.

Not surprisingly, all the developed economies surveyed were above the average score, with the exception of Italy, but developing countries were also included in the above-average category. The Asian 'Tigers' are good examples of countries in which governments actively educated for (maths, engineering, physics, chemistry, accounting, management, IT/IS), and encouraged the creation of, new small businesses.

Again, not surprisingly, the United States, which has a particularly pro-private sector culture, is seen as a good place for entrepreneurs to start new business firms. In the US one can obtain real risk-capital, with a good idea and a sound business plan, to develop, for example, a personal, small computer in one's mother's garage. 
As suggested earlier, the perceptions of young people in Africa, even university business graduates, are not characterised clearly by the excitement and possibility inherent in starting a new business, eventually becoming self-reliant, and employing fellow countrymen and women.

In addition to concrete action, then, in addition to increased domestic and foreign fixed investment, sound macro-economic policies, and a culture of engagement between governments, business sectors and universities, what appears to be required is no less than a major change in perceptions - a significant change in the very mind-set of those who are poised to be the future of this continent.

\section{References}

African Development Bank Group. (2011, June 06). News and Events. Retrieved September 02, 2011, from African Development Bank Group Website: http://www.afdb.org

AGOA. (2011, May 11). AGOA News. Retrieved August 26, 2011, from African Growth and Opportunity Act: http://www.agoa.info

Barnabas, A., Kulkarni, P., Nanavatty, M. \& Singh, R. (1996). The Social Development Summit and The Developing Countries. Social Development Issues , 79-84.

Bendix, R. (1947). Bureaucracy: The Problem and its Setting. American Sociological Review , 493-507. http://dx.doi.org/10.2307/2086730

Birch, D. L. (1979). The Job Creation Process. Cambridge.

Bowditch, N. H. (1999). The Last Emerging Market: From Asian Tigers to African Lions, the Ghana File. Westport CT: Praeger.

Bruderl, J., \& Preisendorfer, P. (2000). fast Growing Businesses: Emperical Evidence from Germany. International Journal of Sociology, 45-70.

Business Innovation and Skills (BIS). (2011). Retrieved August 19, 2011, from BIS Department for Business Innovation and Skills: http://www.bis.gov.uk

CEDA. (2011). Home: CEDA. Retrieved August 20, 2011, from CEDA Web site: http://www.ceda.co.bw

Chuta, E., \& Liedholm, C. (1990). Rural Small Scale Industry: Empirical Evidence and Policy Issues. In C. Eicher, \& J. Staatz, Agricultural Development in the Third World. Baltimore: John Hopkins Press.

Congregational Research Service. (2008). U.S. Trade and Investment Relationship with Sub-Saharan Africa: The African Growth and Opportunity Act and Beyond. Washington DC: Congregational Research Service.

Donner, J. (2008). Research Approaches to Mobile Use in the Developing World: A Review of the Literature. The Information Society, 140-159. http://dx.doi.org/10.1080/01972240802019970

Ekpoh, U. I., \& Edet, A. O. (2011). Entrepreneurship Education and Career Intentions of Tertiary Education Students in Akwa Ibom and Cross River States, Nigeria. International Education Studies , 172-178.

Enterprise Ireland. (2011). Enterprise Ireland. Retrieved August 19, 2011, from http://www.enterprise-ireland.com/en/fundings-supports

Eshima, Y. (2003). Impact of Public Policy on Innovative SMEs in Japan. Journal of Small Business Management, 85-93. http://dx.doi.org/10.1111/1540-627X.00068

Eshun Jr, J. P. (2009). Business Incubation as Strategy. Business Strategy Series , pp. 156-166. http://dx.doi.org/10.1108/17515630910956570

Fatoki, O. O. (2010). Graduate Entrepreneurial Intention in South Africa: Motivations and Obstacles. International Journal of Business and Management, 87-98.

Fritsch, M., \& Hull., C. J. (1987). Empirische Befunde zur Arbeits platzdynamik in grossen und kleinen Unternehmen in der Bundesrepublik Deutschland Eine Zwischenbilanz [Empirical Results on Job Creation in West Germany]. In M. Fritsch, \& C. J. Hull, Arbeitsplatzdynamik und Regionalentwicklung [Job Creation and Regional Development] (pp. 149-72). Berlin: Edition Sigma.

Gaomab, M. (2004, November 28). Country Analysis: Namibia. Retrieved September 29, 2011, from Southern African Regional Poverty Network: http://www.sarpn.org/documents/d0001004/index.php

GlobeScan; The Program on International Policy Attitudes. (2011). BBC World Service Poll: Indonesia and USA 'Most Entrepreneur-Friendly Nations'. London: BBC World Service. 
Haggblade, S., Hazell, P., \& Brown, J. (1989). Farm-Non-Farm Linkages in Rural Sub-Saharan Africa. World Development , 1173-1201. http://dx.doi.org/10.1016/0305-750X(89)90232-5

Hagopian, A., Thompson, M. J., Fordyce, M., Johnson, K. E., \& Gary Hart, L. (2001). The Migration of Physicians from Sub-Saharan Africa to the United States of America: Measures of the African Brain Drain. Human Resources for Health.

Hanson, S. (2008, January 10). Publications: Botswana. Retrieved August 26, 2011, from Coucil on Foreign Relation Website: http://www.cfr.org

Hudson, J. (1996, January). Riding the Tiger: Urban warfare on the East Rand. Terrorism and Political Violence , pp. 103-123. http://dx.doi.org/10.1080/09546559608427374

Ikome, F. (2008). The Social and Economic Consequences of the Global Financial Crisis on the Developing Countries and Emerging Economies: A Focus on Africa. InWent-DIE Dialogue on the Effects of the Global Financial Crisis on Developing Countries and Emerging Markets, (pp. 1-8). Berlin.

Johanson, R. K., \& Adams, A. V. (2004). Skills Development in Sub-Saharan Africa. Washington DC: The International BAnk for Reconstruction and Development/The World Bank. http://dx.doi.org/10.1596/978-0-8213-5680-7

Katono, I. W., Heintze, A., \& Byabashaija, W. (2010). Environmental Factors and Graduate Start Up in Uganda. Conference on Entrepreneurship in Africa. New York: Whitman School of Management Syracuse University .

Klasen, S., \& Woolard, I. (2009). Surviving Unemployment Without State Support: Unemployment and Household Formation in South Africa. Journal of African Economies , 1-51.

Krivo, L. J., Peterson, R. D., Rizzo, H., \& Reynolds, J. R. (1998, February). Race, Segregation, and the Concentration of Disadvantage: 1980-1990. Social Problems , pp. 61-80. http://dx.doi.org/10.1525/sp.1998.45.1.03x0157a

Laishley, R. (2011). United Nations Africa Renewal. Retrieved September 02, 2011, from United Nations: http://www.un.org/ecosocdev/geninfo/afrec/newrels/mixed-signals-on-economy-09.html

LEA. (2011). LEA: About Us. Retrieved August 20, 2011, from Local Enterprise Authority: http://www.lea.co.bw

Leke, A., Lund, S., Roxburgh, C., \& van Wamelen, A. (2010). What's Driving Africa's Growth . McKinsey Quarterly .

Maina, R. W. (2011). Determinants of Entrepreneurial Intentions among Kenyan College Graduates. KCA Journal of Business Administration , 1-18. http://dx.doi.org/10.4314/kjbm.v3i2.65968

Masuko, L., \& Marufu, D. (2003). The Determinants of Transactions Cost And Access to Credit by SMEs and the Poor In Zimbabwe. International Labour Organization.

Mead, D. C. (1994). The Contribution of Small Enterprises to Employment Growth in Southern and Eastern Africa. World Development , 1881-1894. http://dx.doi.org/10.1016/0305-750X(94)90180-5

Mlatsheni, C., \& Rospabé, S. (2002). Why is Youth Unemployment so High and Unequally spread in South Africa? Development Policy Research Unit Working Paper 02/65 .

Morewagae, B. S., \& Seemule, M. (1995). Access to Credit for Non-Formal Micro-Enterprises in Botswana. Journal of Development Studies , 481. http://dx.doi.org/10.1080/00220389508422374

Motseta, S. (2011, May 11). Batswana entrepreneurs fail to use AGOA. The Botswana Gazette . Gaborone, Botswana: The Botswana Gazette.

Mutula, S. M. (2002). The Cellular Phone Economy in the SADC Region: Implications for Libraries. Online Information Review , 26 (2).

Nelson, E. G., \& De Bruijn, E. J. (2005). The Voluntary Formalization of Entreprises in a Developing Economy - The Case of Tanzania. Journal of International Development, 575-93. http://dx.doi.org/10.1002/jid.1176

Nwigwe, C. J. (2010). Promoting youth entrepreneurship in Lagos, Nigeria. Retrieved September 29, 2011, from http://academicarchive.snhu.edu

OECD. (2010, July). OECD Studies on SME's and Entrepreneurship SME's, Entrepreneurship and Innovation: Complete Edition . OECD/Studies/Industry, Services \& Trade, pp. 1-228.

Organization for Economic Cooperation and Development (OECD). (1994). Industrial Policy in OECD Countries. Paris, France.: OECD. 
Plattner, I. E., Lechaena, M., \& Mmolawa, W. (2009). Are University Students Psychologically Ready for Entrepreneurship? A Botswana Study. African Journal of Business Management, 305-310.

Population Reference Bureau. (2011). 2009 World Population Data Sheet. Retrieved October 25, 2011, from Population Reference Bureau Website: http://www.prb.org/Publications/Datasheets/2009/2009wpds.aspx

Salami, C. G. (2011). Entrepreneurial Interventionism and Challenges of Youth Unemployment in Nigeria. Global Journal of Management and Business Research .

Savoie, D. J. (1994). Thatcher, Reagan and Mulroney: In Search of New Bureaucracy. Pittsburg: University of Pittsburg Press.

Schwartz, R. E. (1996). Wireless Communications in Developing Countries: Cellular and Satellite Systems. Norwood, MA, USA : Artech House, Inc.

Shrum, W., Mbatia, P. N., Palackal, A., Dzorgbo, D.-B. S., Duque, R. B., \& Ynalvez, M. A. (2011). Mobile Phones and Core Network Growth in Kenya: Strengthening Weak Ties. Social Science Research, 614-625. http://dx.doi.org/10.1016/j.ssresearch.2010.09.015

Sirolli, E. (1999). Ripples in the Zambezi. Gabriola Island: New Society Publishers.

Storey, D. J. (1994). Understanding the Small Business Sector. London: Routledge.

Studman, C. (2003). Growing a Research Culture. Journal of Research Administration, 19-28.

The Economist. (2010, May 06). A black middle class is emerging, but poverty and crime blight millions of lives . The Great Scourges .

The Economist. (2011, January 06). Daily Chart. Retrieved September 02, 2011, from The Economist: http://www.economist.com

USAID. (2011, July 20). Sectors: Economic Growth and Trade. Retrieved September 02, 2011, from USAID Website: http://www.usaid.gov

van Dalen, H. P., Groenewold, G., \& Schoorl, J. J. (2005). Out of Africa: What Drives the Pressure to Emigrate? Journal of Population Economics , 741-78. http://dx.doi.org/10.1007/s00148-005-0003-5

Wacquant, L., \& Wilson, W. (1989). Cost of Racial and Class Exclusion in the Inner City. Annals of the American Academy of Political and Social Science, 8-25. http://dx.doi.org/10.1177/0002716289501001001

Walter, T., Rosa, P., Barabas, S., Balunywa, W., Sserwanga, A., Namatovu, R., et al. (2004). GEM Uganda 2004 Executive Report. Kampala: Global Entrepreneurship Monitor Uganda. 